\title{
Bioerosion of experimental substrates on high islands and on atoll lagoons (French Polynesia) after two years of exposure
}

\author{
N. Pari ${ }^{1,2, *}$, M. Peyrot-Clausade ${ }^{1}$, T. Le Campion-Alsumard ${ }^{1}$, P. Hutchings ${ }^{3}$, \\ V. Chazottes ${ }^{2}$, S. Golubic ${ }^{4}$, J. Le Campion ${ }^{1}$, M. F. Fontaine ${ }^{1}$ \\ ${ }^{1}$ Centre d'Océanologie de Marseille, UMR CNRS 6540, Université de la Méditerranée, Station Marine d'Endoume, \\ rue de la Batterie des Lions, F-13007 Marseille, France \\ ${ }^{2}$ Centre de Sédimentologie et Paléontologie, UPRESA CNRS 6019, Université de Provence, Aix-Marseille I, case 67, \\ F-13331 Marseille cedex 03, France \\ ${ }^{3}$ The Australian Museum, 6-8 College Street, 2000 Sydney, New South Wales, Australia \\ ${ }^{4}$ Department of Biology, Boston University, Boston, Massachusetts 02215, USA
}

\begin{abstract}
Rates of bioerosion by grazing and boring were studied in lagoons of 2 high islands ( 3 sites) and 2 atolls ( 2 sites each) in French Polynesia using experimental carbonate substrates (blocks of Porites lutea skeleton). The substrate loss versus accretion was measured after 6 and 24 mo of exposure. The results show significant differences between pristine environments on atolls and environments on high islands subjected to different levels of eutrophication and pollution due to human activities. Whereas experimental substrates on the atolls maintain a balance between accretion and erosion or exhibit net gains from accretion (positive budget), only 1 site on a high island exhibits significant loss of substrate by net erosion (negative budget). The erosional patterns set within the first 6 mo of exposure were largely maintained throughout the entire duration of the experiment. The intensity of bioerosion by grazing increases dramatically when reefs are exposed to pollution from harbour waters; this is shown at one of the Tahiti sites, where the highest average bioerosional loss, up to $25 \mathrm{~kg}$ $\mathrm{m}^{-2} \mathrm{yr}^{-1}\left(6.9 \mathrm{~kg} \mathrm{~m}^{-2} \mathrm{yr}^{-1}\right.$ on a single isolated block), of carbonate substrate was recorded.
\end{abstract}

KEY WORDS: Bioerosion - Experimental substrates · Coral reefs · French Polynesia

\section{INTRODUCTION}

Coral reefs are dynamic systems characterized by a delicate balance between reef growth and reef destruction, the latter primarily caused by bioerosion of coral substrate by grazing and boring organisms (Hutchings 1986). Excessive bioerosion weakens the structure of the reef framework and makes it more susceptible to damage by cyclones and storms (HarmelinVivien 1994), by El Nin̄o events (Glynn 1994, Eakin 1996), and by coral predators such as the Crown-ofThorns starfish (Musso 1997). Direct and indirect impact of bioerosion on coral reef structures, both recent and ancient, has been widely recognized

•E-mail: pari@com.univ-mrs.fr
(Bromley 1975, Bromley \& D'Alessandro 1990, Fiege 1993, Glynn 1997). However, only limited information is available on agents and rates of bioerosion. Experimental studies on bioerosion rates in the Indo-Pacific region have been carried out on the Great Barrier Reef, Australia at Lizard Island (Hutchings et al. 1992, Kiene \& Hutchings 1994a, b, Musso 1997) and One Tree Island (Kiene 1985, 1988) and on Britomart Reef (Sammarco et al. 1987), which includes a cross-shelf transect (Sammarco \& Risk 1990). Other studies were carried out on the reefs of Moorea, French Polynesia (Chazottes et al. 1995), and at Réunion Island, Indian Ocean (Chazottes 1996). Reaka-Kudla et al. (1996) have recently undertaken experimental studies on a highly degraded reef at Champion Island in the Galapagos. Most of these quantitative studies have 
revealed variations within a single reef system. These variations need to be evaluated in their respective regional contexts before they can be incorporated into generalized coral reef budgets.

Therefore, in 1990 we initiated a study of regional variations in bioerosion on high island and atoll coral reefs in French Polynesia. The preliminary results, following $6 \mathrm{mo}$ of exposure of Porites skeleton blocks, revealed considerable differences between sites (PeyrotClausade et al. 1995b). High densities of algal turf at one polluted site were found to be correlated with large numbers of Echinometra mathaei and with extremely high rates of bioerosion, primarily caused by these sea urchins. From our preliminary results the following questions arose: (1) How does bioerosion vary over time? (2) Is the contrast between atolls and high islands found after 6 mo (Peyrot-Clausade et al. 1995a) maintained after longer exposure? (3) Are these results different from those obtained elsewhere on similar experimental substrates?

This paper presents the results of bioerosion after $2 \mathrm{yr}$ of exposure of coral blocks. It discusses the changes in rates and agents of bioerosion over time, both within and between sites and compares our results with those obtained elsewhere.

\section{MATERIALS AND METHODS}

Location and description of study sites. Seven sites were selected: 3 on the fringing reefs of high islands [2 on Tahiti $\left(17^{\circ} 40^{\prime} \mathrm{S}, 149^{\circ} 30^{\prime} \mathrm{W}\right.$ ) and 1 on Moorea $\left(17^{\circ} 30^{\prime} \mathrm{S}, 149^{\circ} 50^{\prime} \mathrm{W}\right.$ ), Society Archipelagol and 4 (2 on each atoll) on lagoon pinnacles on 2 atolls (Takapoto $\left(14^{\circ} 30^{\prime} \mathrm{S}, 145^{\circ} 20^{\prime} \mathrm{W}\right)$ and Tikehau $\left(15^{\circ} 00^{\prime} \mathrm{S}, 148^{\circ} 10^{\prime} \mathrm{W}\right)$, Tuamotu Archipelago, French Polynesia] (Fig. 1). All sites were located in water depths of 1 to $2 \mathrm{~m}$. Full details of the 7 study sites are given in PeyrotClausade et al. (1995b); brief descriptions are given in the following.

(1) Faaa, Tahiti, is located in Papeete harbour at the mouth of the Tiparui River, which carries large quantities of terrigenous sediments and domestic sewage during the annual rainy season (Fraizier et al. 1985). (2) Atimaono, Tahiti, is a patch reef $100 \mathrm{~m}$ offshore well away from urban populations. This site has numerous live coral colonies, a diverse assemblage of other colonial reef organisms (Gabrié et al. 1986) and good water quality (see Cariès 1991 and Hutchings et al. 1994). (3) Tiahura is a fringing reef at Moorea located about $50 \mathrm{~m}$ offshore. For a description of the coral communities in this area, see Bouchon (1985). Gabrié et al. (1988) and Adjeroud (1996) reported that water quality was consistently good in the area, although Wolanski et al. (1993) showed that under certain weather conditions a build up of nutrients may occur in the area from the discharge of nearby resort developments.

Takapoto is a closed elongated atoll with many lagoonal pinnacles. Salvat \& Richard (1985) described the lagoonal coral communities and reported salinity levels varying from 35.5 to $36.1 \mathrm{ppt}$ in the course of 1979. The waters are oligotrophic (Charpy 1996). (4) Tak. 1 was selected at the north end of the Takapoto lagoon in the Takai area. The experimental substrates were placed on the leeward side of a pinnacle. (5) Tak. 2 was selected in the mid part of the Takapoto lagoon at the Teavatika hoa, a small channel through which exchanges of oceanic and lagoonal water occur during storm conditions.

Tikehau is an almost circular atoll with one pass (Harmelin-Vivien 1985, Peyrot-Clausade 1989). The coral communities on the lagoonal pinnacles are zoned according to depth and exposure and were described by Faure \& Laboute (1984) and Harmelin-Vivien (1985). Water quality was reported as oligotrophic (Charpy 1996). (6) Tik. 1 was selected at leeward side of a pin- 
nacle at the southern end of the lagoon, close to a functional hoa. (7) The Tik. 2 site was selected at the leeward side of a pinnacle located more to the centre of the lagoon, but closer to the main village than site Tik. 1

Experimental substrates. Large live colonies of Porites lutea collected earlier at the Great Barrier Reef were used as the source of substrates for exposure experiments. The skeletons without endolithic boreholes were cut into regular sized blocks $(8 \times 4 \times 4 \mathrm{~cm})$ using a band saw. Each block was soaked in sodium hypochlorite to remove organic matter, rinsed in freshwater for several days and dried. Dry weight and linear measurements were taken, and each block was provided with a unique number. The surfaces of all blocks were uniformly cut and layers with coral polyps removed. A representative piece of each colony was stored for reference. The density of each block was determined by the relationship between the dry weight and the block volume. Blocks were attached in situ with aqua cement to large heads of dead Porites lutea. The dead Porites colonies were cut flat before mounting of the blocks. Twenty blocks were placed on each site in November 1990 to be removed sequentially after exposure periods of 6 mo (Peyrot-Clausade et al. 1995b) and 24 mo. For each period, 5 replicates were collected from each of the 7 sites. For the present study, blocks were collected in November 1992 after 2 yr of exposure.

Treatment after exposure. After exposure, each block was tixed in a buffered $3 \%$ solution of formaldehyde in seawater. Any remaining aqua cement on the block was easily removed with a hammer and chisel. The blocks were cut in half and one half was cut vertically into $1 \mathrm{~cm}$ slices. For each block at least 2 slices were analysed. Additional slices were occasionally available for further analyses. Thus, at least 10 slices per site were obtained for analysis. The slices were photographed and the photographs scanned. Image analyses was performed on the scanned images using the program Optilab.

The rates of accretion were determined from scanned photographs of the slices. The surface area covered with crustose coralline algae and the mean thickness of accretion were measured by image analysis, which allowed the volume of coralline algal accretion per slice to be calculated. Using a density of $1.26 \mathrm{~g} \mathrm{~cm}^{-3}$ for calcareous algae (Laubier 1962), the mass and rate of accretion could be estimated.

The rates of external erosion by grazing were also determined from scanned photographs of the slices. The perimeter of and surface area under the encrusting organisms on each slice were measured using image analyses. The volume of the remaining substrate was calculated for each $1 \mathrm{~cm}$ thick slice from the measured surface areas. The difference between initial and final volumes represents the volume of the slice lost during exposure. Using the density value measured for each block prior to exposure, the rate of calcium carbonate loss by external erosion expressed as $\mathrm{kg} \mathrm{m}^{-2} \mathrm{yr}^{-1}$ could be estimated.

The rates of internal erosion by macroborers were calculated on the basis of carbonate volume removed (see above), which was determined from outlines of borings visible on scanned slices and evaluated using image analysis.

The rates of net erosion were determined from accretion minus erosion (external plus internal) for each slice; the average rate for each block was determined and the mean and standard deviations (based on at least 10 values) were calculated for each site. The data are presented as net rates of change of calcium carbonate in $\mathrm{kg} \mathrm{m}^{2} \mathrm{yr}^{-1}$.

The total organic matter (epilithic and endolithic flora and fauna) resident in the block, which is potential food for the grazers, was estimated on the basis of several $1 \mathrm{~cm}^{3}$ cubes cut from the exposed surfaces of 1 slice per block. These $1 \mathrm{~cm}^{3}$ samples were rinsed with deionized water and dried to constant mass at $60^{\circ} \mathrm{C}$. Dry samples were heated to $550^{\circ} \mathrm{C}$ for $5 \mathrm{~h}$ to remove organic matter, and weighed. For each slice, 8 cubes were selected, 2 from the top surface and 3 from each side, and the results were expressed as $\mathrm{mg} \mathrm{cm}^{-3}$ (mean \pm standard deviation). A previous study (Peyrot-Clausade et al. 1995b) had shown that using 4 cubes selected at random provided a relatively large error $(20 \%)$ of the mean (see Bliss 1967 and Sachs 1982) for both epilithic and endolithic algal biomasses. The method used by Peyrot-Clausade et al. (1995b) for calculating the organic biomass from decalcified dry mass per unit area was found to be an underestimate, and after different statistical tests a correction factor of 3.5 was needed to convert these figures to be comparable with those obtained by organic matter combustion, as used in our study for blocks exposed for 2 yr (see Table 1 ).

Biomass and density of macroborers were determined on the other half of the block which remained unsliced. This half was treated with a mixture of formalin and hydrochloric acid (for details see Hutchings \& Weate 1978) to dissolve calcium carbonate, which facilitates the removal of all the macroborers (Hutchings 1981). Polychaetes, sipunculans and vermetid molluscs were counted and wet weighed (in mg to 3 decimal places) just after blotting The wet weight was converted to $\mathrm{mg}$ per $100 \mathrm{~cm}^{3}$

The number of sea urchins Echinometra mathaei present at each site was estimated from counts of individuals in 20 random quadrats of $0.25 \mathrm{~m}^{2}$ made in November 1992 at the time of collection of blocks. These densities were compared with those present at the sites after 6 mo of exposure (Peyrot-Clausade et al. 1995b).

Statistical analyses. The univariate data display (box plots) developed by Tukey (Frigge et al. 1989) was 
used. Each sample is represented as a box, divided at the median, and 2 wiskers; the box length is the interquartile range and the wisker ends correspond to the first and the last decile. All the observations beyond these limits are plotted individually.

A series of 1-way analyses of variance (ANOVAs) was carried out to investigate the variation in the net rates of erosion (accretion minus erosion) among blocks within a site and among the sites (Bliss 1967).

Subsequently a series of 1 -way ANOVAs was also carried out to investigate the effects of site on various parameters (rates of accretion, external erosion, internal erosion, organic matter present in the surface $1 \mathrm{~cm}$ layer of the substrate, composition and biomass of infaunal communities) after 2 yr of exposure. Two-way ANOVAs with equal replication (cross classification) were then carried out on each of the above parameters obtained after 6 mo and 2 yr of exposure to investigate the effects of site and length of exposure. Multiple comparison of means according to Student-Newman-Keuls (SNK) test (Zar 1984) were used to determine which of these means were significantly different from each other. In both sets of ANOVAs the mean values for each block were used.

The classification of the blocks exposed for $2 \mathrm{yr}$ was made using the Ward method (Euclidean distance on standardised data; Saporta 1978), and confirmed by centroid clustering (Roux 1985). The parameters considered were rates of accretion, external erosion, internal erosion, organic matter, biomass of polychaetes and sipunculans; their contribution to each cluster (class) was established as in Principal Component Analysis (PCA) (Roux 1985).

Using 2-way ANOVA, the interaction between the factors (sites and periods) was analysed and illustrated by means of diagrams. For each site the difference between mean values obtained after 6 mo and 24 mo was established with $95 \%$ confidence interval.

All the analyses were performed on log transformed data to reduce the skewed distribution of the original data and the homoscedasticity using the statistical packages Super Anova 1.11 (1991), Statview 4.5 (1996) and Stat-Itcf (1991).

\section{RESULTS}

\section{Rates of accretion}

The mean rates of accretion varied among sites, the maximum value of $1.13 \pm 0.54 \mathrm{~kg} \mathrm{~m}^{-2} \mathrm{yr}^{-1}$ was recorded at Tik. 1 and the minimum value of $0.18 \pm 0.19 \mathrm{~kg} \mathrm{~m}^{-2}$ $\mathrm{yr}^{-1}$ at Faaa (Table 1). A 1 -way ANOVA revealed that significant differences ( $p=0.0008$ ) occurred among the sites (Table 2). A SNK test showed that the rate of accretion was significantly higher at Tik. 1 (where the

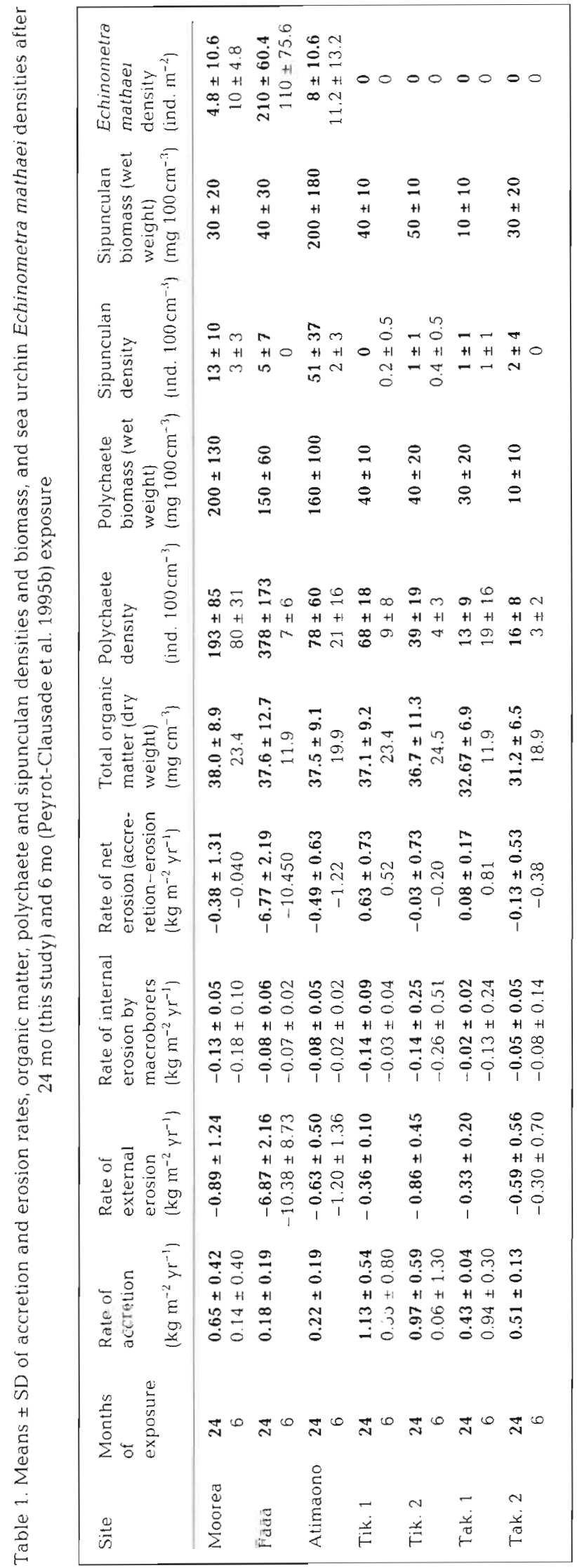


blocks gained about $16 \%$ of their original volume) than at the Tahiti sites (Faaa and Atimaono) (Fig. 2). The other 4 sites (Moorea, Tak. 1 and 2 and Tik. 2) had intermediate overlapping values. The variability within sites was particularly low in Takapoto (Fig. 3).

\section{Rates of external erosion}

Estimated rates of $\mathrm{CaCO}_{3}$ loss by external erosion were highest at Faaa $\left(6.87 \pm 2.16 \mathrm{~kg} \mathrm{~m}^{-2} \mathrm{yr}^{-1}\right)$ and lowest at Tak. $1\left(0.33 \pm 0.20 \mathrm{~kg} \mathrm{~m}^{-2} \mathrm{yr}^{-1}\right)$ (Table 1). A 1 -way ANOVA revealed that significant differences ( $p=0.0001$ ) occurred among sites (Table 2). A SNK test showed that the amount of external erosion was significantly higher at Faaa (where the blocks lost about $50 \%$ of their original volume) than at the other 6 sites (Fig. 2). A 1-way ANOVA excluding the site at Faaa showed that no significant differences in rates of external erosion occurred among the other 6 sites $(\mathrm{p}=$ 0.5282 ). In addition, the variability within each site was low except at Moorea and particularly at Faad, as shown by box plots (Fig. 3).

Table 2. One-way ANOVA among sites. Data were rates of accretion, external and internal erosion, net erosion, organic biomass and density and biomass of polychaetes and sipunculans. The original data were transformed before analysis, according to the logarithmic transformations $\log x$ or $\log (x+1)$

to ameliorate distribution skewness and homoscedasticity

\begin{tabular}{|c|c|c|c|c|}
\hline Source of variation & $\mathrm{df}$ & MS & $F$ & $\mathrm{p}$ \\
\hline \multicolumn{5}{|l|}{ Accretion } \\
\hline Site & 6 & 0.186 & 5.619 & 0.0008 \\
\hline Residual & 26 & 0.003 & & \\
\hline \multicolumn{5}{|l|}{ External erosion } \\
\hline Site & 6 & 7.073 & 5.712 & 0.0001 \\
\hline Residual & 26 & 1.236 & & \\
\hline \multicolumn{5}{|l|}{ Internal erosion } \\
\hline Site & 6 & 0.007 & 1.050 & 0.4167 \\
\hline Residual & 26 & 0.007 & & \\
\hline \multicolumn{5}{|l|}{ Net erosion } \\
\hline Site & 6 & 36.345 & 26.016 & 0.0001 \\
\hline Residual & 26 & 1.397 & & \\
\hline \multicolumn{5}{|l|}{ Organic matter } \\
\hline Site & 6 & 0.209 & 3.479 & 0.0026 \\
\hline Residual & 26 & 0.6 & & \\
\hline \multicolumn{5}{|l|}{ Polychaete density } \\
\hline Site & 6 & 8.082 & 19.452 & 0.0001 \\
\hline Residual & 26 & 0.415 & & \\
\hline \multicolumn{5}{|l|}{ Polychaete biomass } \\
\hline Site & 6 & 3.545 & 5.868 & 0.0006 \\
\hline Residual & 26 & 0.604 & & \\
\hline \multicolumn{5}{|l|}{ Sipunculan density } \\
\hline Site & 6 & 8.571 & 11.430 & 0.0001 \\
\hline Residual & 26 & 0.750 & & \\
\hline \multicolumn{5}{|l|}{ Sipunculan biomass } \\
\hline Site & 6 & 0.018 & 3.706 & 0.0001 \\
\hline Residual & 26 & 0.005 & & \\
\hline
\end{tabular}

From the photographs taken at the end of the exposure series at Faaa, it was possible to measure the decrease of coral patches where blocks were attached (Peyrot-Clausade et al. 1995a). The rate of carbonate removal was estimated from these photographs at $25.14 \pm 2.40 \mathrm{~kg} \mathrm{~m}^{-2} \mathrm{yr}^{-1}$.

\section{Rates of internal erosion by macroborers}

Boring activities by macrofaunal animals were highest at the 2 sites at Tikehau $(0.14 \pm 0.09$ and $0.14 \pm$ $0.25 \mathrm{~kg} \mathrm{~m}^{-2} \mathrm{yr}^{-1}$ ) and lowest at the 2 sites at Takapoto $\left(0.02 \pm 0.02\right.$ and $\left.0.05 \pm 0.05 \mathrm{~kg} \mathrm{~m}^{-2} \mathrm{yr}^{-1}\right)$ (Table 1$)$. However no significant differences among the sites $(\mathrm{p}=$ 0.4167 ) were revealed by the 1-way ANOVA (Table 2). The variability within each site was limited, as shown on the box plot, except at Tik. 2 (Fig. 3). The box plots show that at 5 sites out of 7 the median is not superposed with the mean, confirming the asymmetrical distribution of these data.

\section{Rates of net erosion (accretion minus external and internal erosion)}

Variations in the net rates of erosion (balance between losses due to erosion and gains due to accretion) were tested. The variance in erosion rates among blocks was at least 7 times greater than the variation within blocks (as determined from the individual slices from one block). Similarly the variance of rates of net erosion among sites was 1.7 times greater than the variability within sites.

The balance between rates of erosion (both by grazers and borers) and accretion varied significantly among sites ( $p=0.0001$ ), with erosional processes prevailing at all sites except at Tak. 1 and Tik. 1 (Table 2). The highest net rate of loss was recorded at Faaa with an estimated net loss of $6.77 \pm 2.19 \mathrm{~kg} \mathrm{~m}^{-2} \mathrm{yr}^{-1}$, while Tak, 1 and Tak. 2 exhibited small mean net gains of $0.08 \pm 0.17$ and $0.63 \pm 0.73 \mathrm{~kg} \mathrm{~m}^{-2} \mathrm{yr}^{-1}$, respectively.

It is obvious that the SNK test showed that only Faaa was significantly different from the other sites (Fig. 2). The box plots (Fig. 3) show that the other 6 sites vary slightly around a balance between accretion and erosion.

\section{Total organic matter}

The amount of organic matter (consisting mainly of algae, sponges, micropolychaetes and sipunculans) was highest at Moorea $\left(38.0 \pm 8.9 \mathrm{mg} \mathrm{cm}^{-3}\right)$ and lowest at Tak. $2\left(31.2 \pm 6.5 \mathrm{mg} \mathrm{cm}^{-3}\right)$ (Table 1). A 1-way ANOVA 


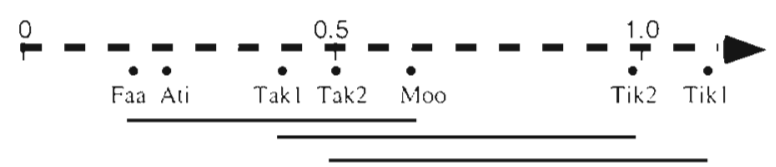

Accretion $\left(\mathrm{kg} \mathrm{m}^{-2} \mathrm{yr}^{-1}\right)$
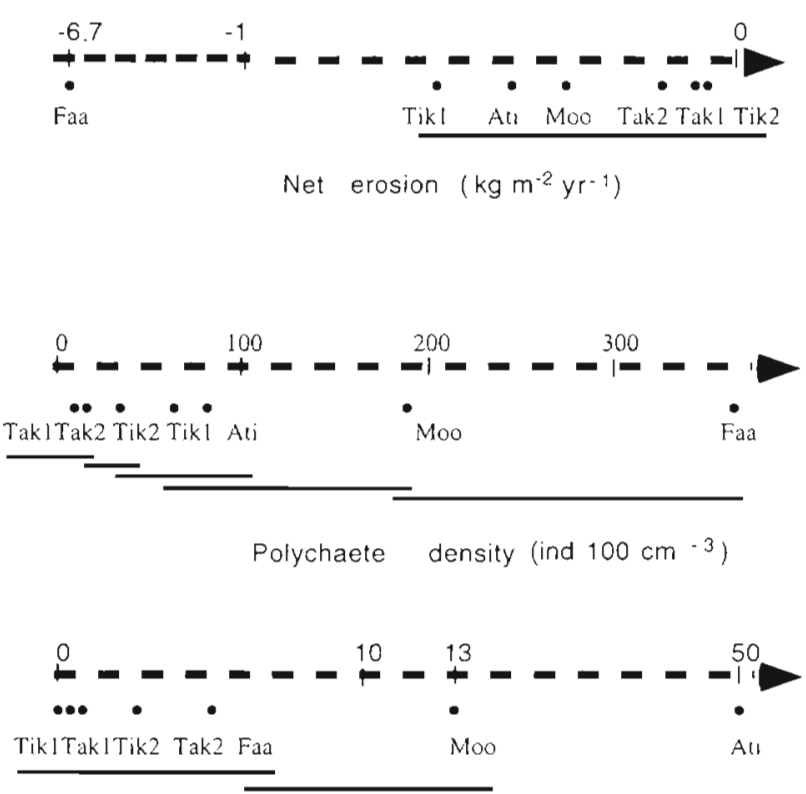

Sipunculan density (ind $100 \mathrm{~cm}^{-3}$ )

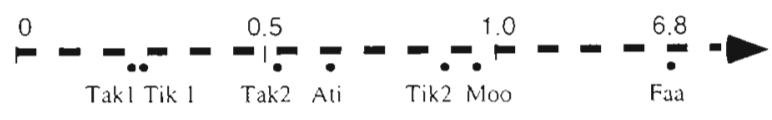

External erosion $\left(\mathrm{kg} \mathrm{m}^{-2} \mathrm{yr}^{-1}\right)$
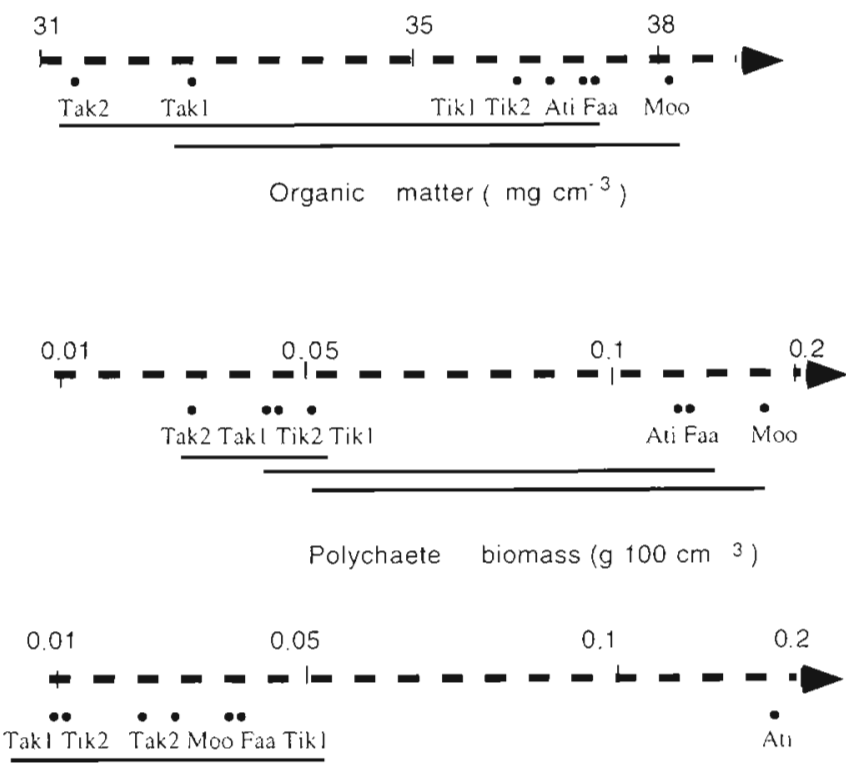

Sipunculan biomass $\left(g 100 \mathrm{~cm}^{-3}\right)$

Fig. 2. Student-Newman-Keuls multirange test applied to the data analysed in Table 2. Significance level, $\alpha=0.05$. Sites are ranked by mean; means sharing the same underline are not significantly different. Faa: Faaa; Ati: Atimaono; Moo: Moorea

revealed that the amount of organic biomass differed significantly among sites ( $\mathrm{p}=0.0026$ ) (Table 2 ). A SNK test showed the highest value for Moorea and the lowest for Tak. 2 (Fig. 2), the other sites exhibiting intermediate overlapping values. Box plots revealed a low variability within sites (Fig. 3).

\section{Density and biomass of macroborers}

Polychaetes represented by 9 species (species lists will be published separately) dominated the macroborer communities, in terms of the number of individuals (Table 1). A 1-way ANOVA revealed that a significant difference ( $p=0.0001)$ occurred among the sites (Table 2) with regard to the density of polychaetes present. A SNK test based on polychaete densities indicated that the 2 sites at Takapoto were grouped and differed significantly from Moorea and Faaa, with the other sites overlapping (Fig. 2). Box plots indicated very high values and variability in the density of polychaetes on high island sites Faaa, Moorea and Atimaono (Fig. 3).
A 1-way ANOVA showed that the biomass of polychaetes differed significantly among the various sites ( $p=0.0006$, Table 2), with the highest biomass being recorded at Moorea $\left(200 \pm 130 \mathrm{mg} 100 \mathrm{~cm}^{-3}\right.$ of block) and the lowest at Tak. $2\left(10 \pm 10 \mathrm{mg} 100 \mathrm{~cm}^{-3}\right.$ of block $)$. A SNK test based on the biomass of polychaetes showed that Moorea was significantly higher than Tak. 1 and 2 and Tik. 2. The other sites exibited intermediate overlapping values. Most polychaetes were very small; thus their biomass was very low despite high densities found locally (in Moorea: $193 \pm 85$ ind $100 \mathrm{~cm}^{-3}$ of block)

Six species of sipunculans were present in the samples. A 1-way ANOVA revealed a significant difference ( $p=0.0001$; Table 2 ) among sites with regard to the density of sipunculans present. A SNK test based on the density of sipunculans present showed Atimaono was significantly highest with $51 \pm 37$ ind. $100 \mathrm{~cm}^{-3}$ of substrate (Table 1), and that the atoll sites were low and grouped together with Faaa, Moorea being intermediate (Fig. 2).

A box plot revealed the great variability in the distribution of sipunculans among replicates on high island 

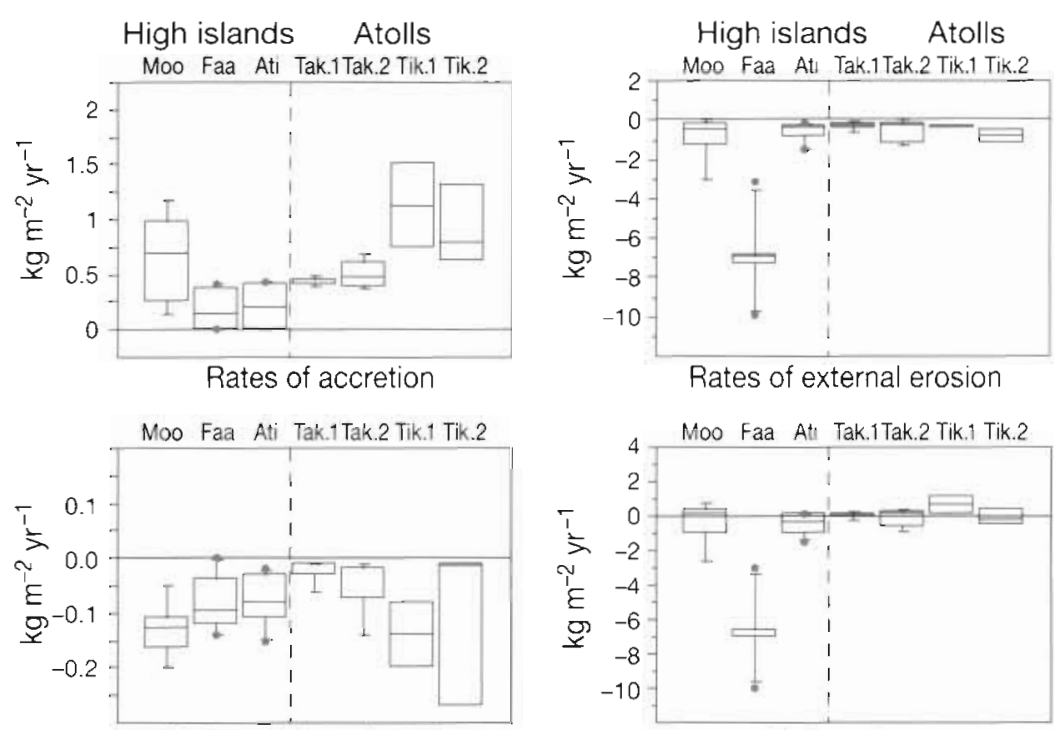

Rates of internal erosion
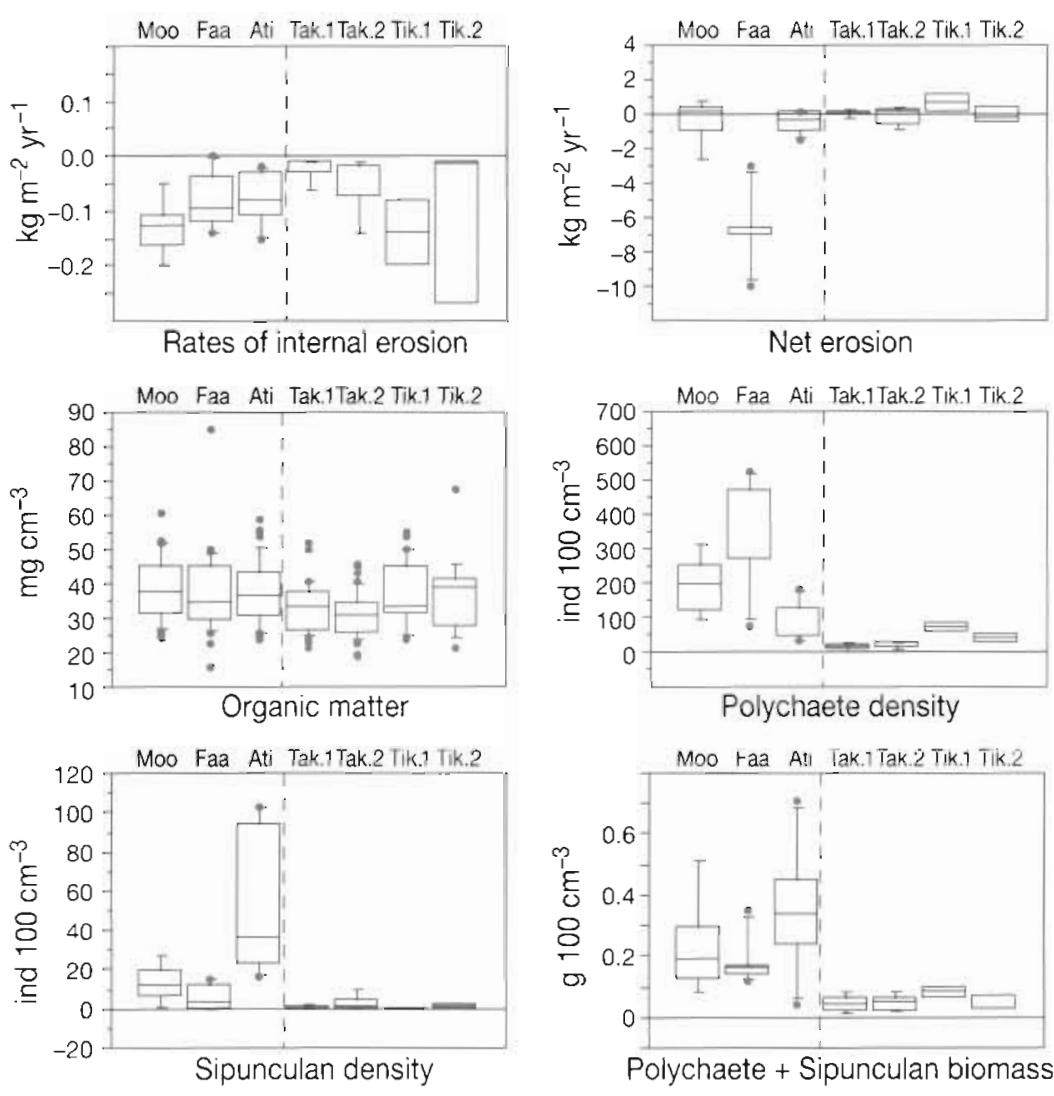

Net erosion
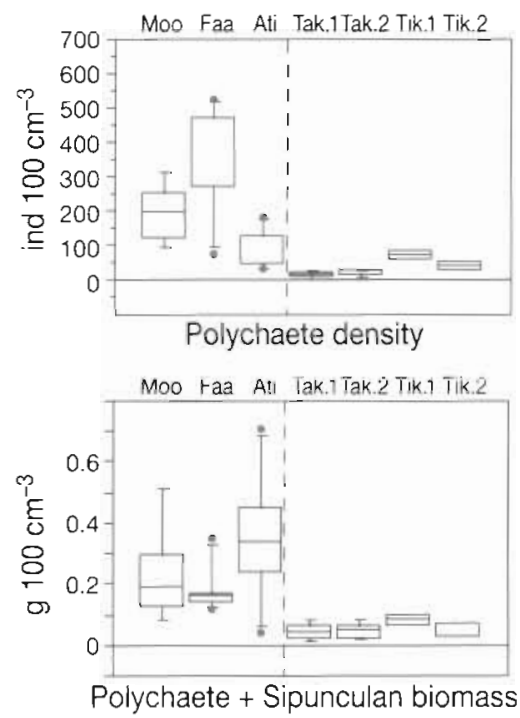

Fig. 3. Box plots of calculated rates of accretion and erosion, total organic matter accumulated in the exposed substrates, densities and biomass of polychaetes and sipunculans after 2 yr of exposure. ( ) Outlier. Site abbreviations as in Fig. 2

Only 2 blocks, 1 at each of the 2 sites at Tikehau, were infested by the sponge Cliona vastifica and rates of internal bioerosion were much higher in these blocks than in other samples (0.2 and $0.5 \mathrm{~kg} \mathrm{~m}^{-2} \mathrm{yr}^{-1}$ ) but not sufficient to induce a difference among sites.

\section{Density of sea urchins}

The sea urchins Echinometra mathaei were present only at the high island sites (Table 1). A 1-way ANOVA showed that Faaa with its high density of sea urchins $\left(210 \pm 60.4\right.$ ind. $\left.\mathrm{m}^{-2}\right)$ was significantly different from sites at Moorea and Atimaono $(p=0.0001)$.

\section{Classification of sites}

The results of the cluster analysis revealed 5 groups of blocks (Fig. 4). An analysis of the factors contributing to these groupings revealed that for Group 1 (blocks from Moorea and Atimaono, together with 1 block from Faad) the most important variable was the biomass of polychaetes and sipunculans, which contributed $84 \%$ to the clustering. For Group 2 (blocks from Moorea, Atimaono, Tak. 2 and Tik. 1 and 2) $47 \%$ was contributed by organic matter content, $33 \%$ by net rates of accretion and $13 \%$ by external erosion. For Group 3 (Faaa) the most important variable, contributing $83 \%$ to the clustering, was the external erosion with extremely high rates, and

sites (Fig. 3) particulary for Atimaono, which had positive skewness.

A 1-way ANOVA of the biomass of sipunculans revealed differences among sites ( $p=0.0001$; Table 2$)$, and a SNK test showed that Atimaono was significantly different from the others sites (Fig. 2), with the highest biomass of sipunculans recorded (200 $\pm 180 \mathrm{mg}$ $100 \mathrm{~cm}^{-3}$ of block).

A box plot based on total biomass of polychaetes and sipunculans indicated high values and more variability within sites of high islands (Fig. 3).

Vermetid molluscs were only abundant on 2 blocks at Moorea, with densities of 4 and 17 ind. $100 \mathrm{~cm}^{-3}$. No other group of molluscs was found.
Group 4 (blocks from Tak. 1, Tak. 2 and Tik. 2) is characterized by similar contributions from rates of internal erosion and biomass of polychaetes and sipunculans (about $30 \%$ each), and also a smaller contribution from the organic matter present. Group 5 (consisting of just 1 block from Tik. 2) was characterized by a single factor, contributing $94 \%$, which was the extremely high rate of internal bioerosion caused by the boring sponge Cliona. It should be noted that none of the sites had replicates that all clustered together, indicating variation within all sites. Two groups were restricted to atoll sites (Groups 4 and 5) and another 2 were composed only of high island sites (Groups 1 and 3). Only one group contained both high island and atolls replicates. 


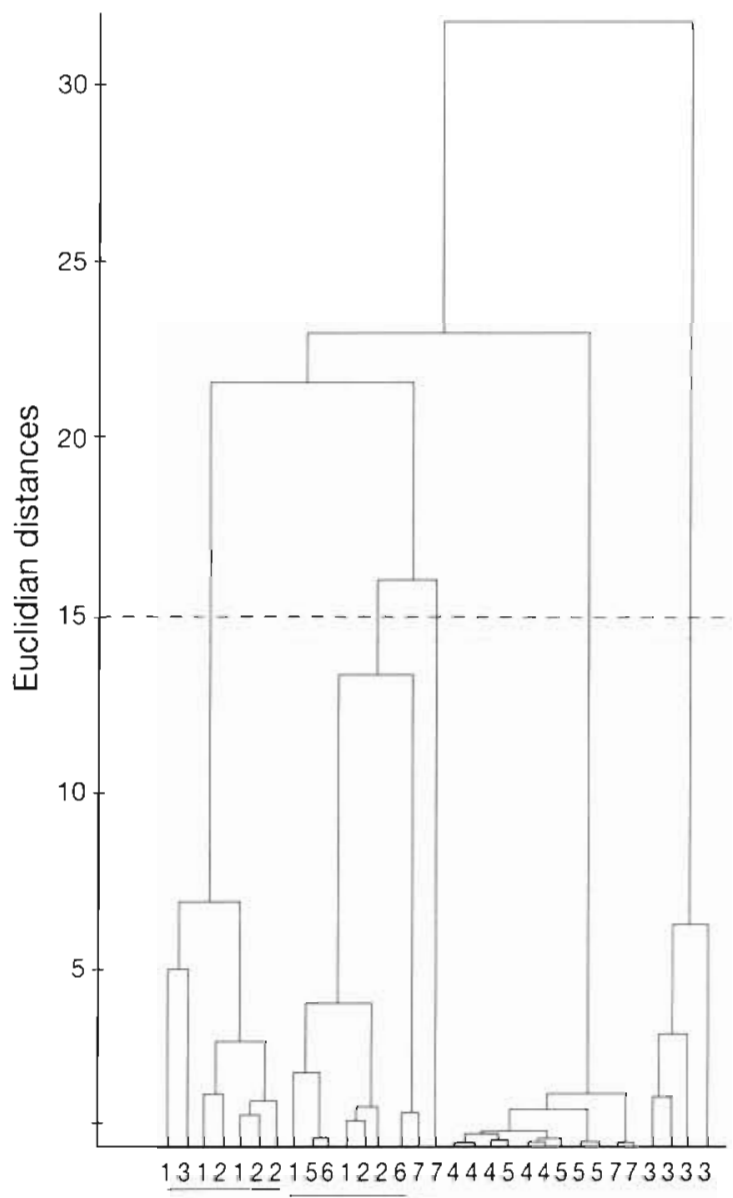

Fig. 4. Dendrogram of cluster analysis results using the Ward method. Each site is represented by all its blocks. Site 1 , Moorea; 2, Atimaono; 3, Faad; 4, Takapoto-1; 5, Takapoto-2; 6 , Tikehau-1; 7 , Tikehau- 2 . The dashed line indicates the cutoff level chosen to separate the groups

\section{Comparison between 6 mo and 2 yr of exposure}

Comparing the results from Peyrot-Clausade et al. (1995b) and those presented here (Table 1) a 2 -way ANOVA (Table 3 ) indicated that the net rates of erosion exhibited significant interaction between sites and sampling periods ( $\mathrm{p}=0.0065$ ). However, Table 3 shows that there is no significant difference between sampling periods $(p=0.0970)$. The diagram established from the difference between mean values from each period for each site revealed that the difference found among sites $(p=0.0001)$ was due essentially to Faaa samples (Fig. 5a). The rate of internal bioerosion exhibited no significant difference between the 2 sampling periods and among sites.

The amount of organic matter present at the 7 sites exhibited significant differences (Table 3 ) for sites $(\mathrm{p}=$ $0.0001)$ and for sampling times ( $p=0.0001)$ with a significant interaction $(\mathrm{p}=0.0001)$. At all sites the amount
Table 3. Two-way ANOVA (nested mixed model) on the net rates of erosion, organic biomass and density and biomass of polychaetes and sipunculans for the 7 sites and the 2 sampling periods ( 6 mo and 2 yr). The original data were transformed before analysis, according to the $\operatorname{logarithmic}$ transformations $\log x$ or $\log (x+1)$, to ameliorate distribution skewness and homoscedastıcity

\begin{tabular}{|c|c|c|c|c|c|}
\hline Source of variation & $\mathrm{df}$ & SS & MS & $F$ & $\mathrm{p}$ \\
\hline \multicolumn{6}{|l|}{ Internal erosion } \\
\hline Site & 6 & 0.144 & 0.024 & 0.718 & 0.6369 \\
\hline Sampling period & 1 & 0.004 & 0.004 & 0.129 & 0.7206 \\
\hline Site $\times$ period & 6 & 0.073 & 0.012 & 0.369 & 0.8991 \\
\hline Residual & 51 & 1.707 & 0.033 & & \\
\hline \multicolumn{6}{|l|}{ Net erosion } \\
\hline Site & 6 & 517.497 & 86.250 & 63.941 & 0.0001 \\
\hline Sampling period & 1 & 3.856 & 3.858 & 2.858 & 0.0970 \\
\hline Site $\times$ period & 6 & 27.669 & 4.612 & 3.419 & 0.0065 \\
\hline Residual & 51 & 68.794 & 1.349 & & \\
\hline \multicolumn{6}{|l|}{ Polychaete density } \\
\hline Site & 6 & 58.639 & 9.773 & 16.151 & 0.0001 \\
\hline Sampling period & 1 & 45.724 & 45.724 & 75.562 & 0.0001 \\
\hline Site $\times$ period & 6 & 21.696 & 3.616 & 5.976 & 0.0001 \\
\hline Residual & 51 & 30.861 & 0.605 & & \\
\hline \multicolumn{6}{|l|}{ Sipunculan density } \\
\hline Site & 6 & 37.076 & 6.179 & 11.909 & 0.0001 \\
\hline Sampling period & 1 & 11.905 & 11.905 & 22.944 & 0.0041 \\
\hline Site $\times$ period & 6 & 15.214 & 2.536 & 4.887 & 0.0001 \\
\hline Residual & 51 & 26.464 & 0.519 & & \\
\hline \multicolumn{6}{|l|}{ Organic matter } \\
\hline Site & 6 & 6.952 & 1.159 & 14.252 & 0.0001 \\
\hline Sampling period & 1 & 28.844 & 28.844 & 3.552 & 0.0001 \\
\hline Site $\times$ period & 6 & 4.821 & 0.804 & 9.884 & 0.0001 \\
\hline Residual & 51 & 24.632 & 0.081 & & \\
\hline
\end{tabular}

of organic matter increased with time, and this was particularly evident at Faaa and Tik. 1 (Fig. 5b).

The densities of polychaetes (Table 3) varied significantly among sites and between sampling periods with a significant interaction ( $p=0.0001)$. At all sites, the number of polychaetes was significantly higher after 2 yr than
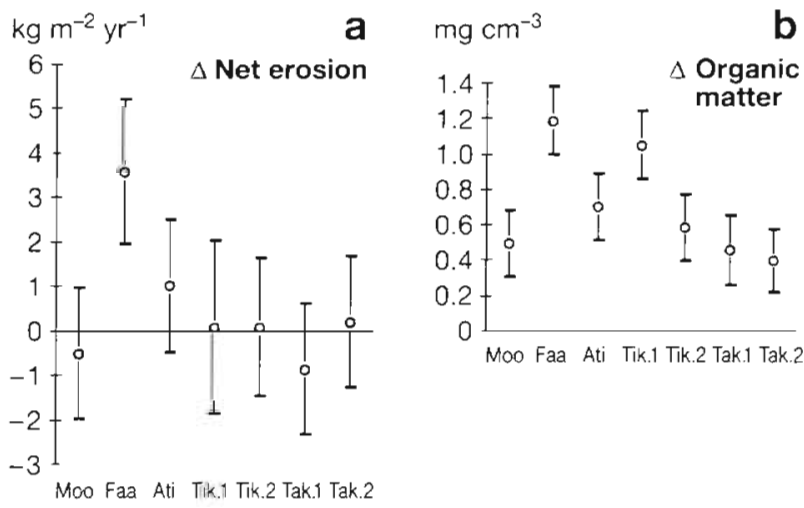

Fig. 5. Interactions between sites and sampling periods. The differences between mean values after 2 yr and 6 mo and the $95 \%$ confidence intervals are shown for each station for (a) net rate of erosion (only Faaa shows a significant interaction) and (b) total organic matter (where there are significant interactions for all the sites) 
after 6 mo. The densities of sipunculans were significantly different (Table 3) for both factors (sites and sampling periods) with a significant interaction $(p=0.0001)$. The densities of sea urchins varied significantly with site $(p=0.0001)$ but not with sam-

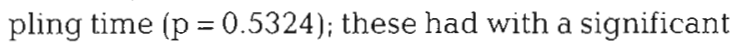
interaction $(\mathrm{p}=0.0027)$.

\section{DISCUSSION}

\section{Agents of bioerosion}

Subsequent to damage and death of the coral colony, the exposed surfaces become available to colonization by epilithic and endolithic flora and fauna, followed by a suite of grazing organisms which feed on such substrates. Various organisms are known to remove substantial quantities of carbonate while grazing on dead coral substrates, including echinoids, scarid fishs, and gastropods (Hutchings 1986, Harmelin-Vivien et al. 1992, Bellwood 1995a, b, Van Treeck et al. 1996). The calculated total rates of net carbonate removal on the 7 sites under study here range between 0.03 (Tik. 2) and $6.77 \mathrm{~kg} \mathrm{~m}^{-2} \mathrm{yr}^{-1}$ (Faaa).

At Faaa, where overfishing has occurred and water quality is severely degraded (Fraizier et al. 1985), rates of loss of block mass by grazing were estimated at $10.38 \pm 8.70 \mathrm{~kg} \mathrm{~m}^{-2} \mathrm{yr}^{-1}$ after $6 \mathrm{mo}$ of exposure. This rate of substrate removal slowed down to annual value of $6.87 \pm 2.16 \mathrm{~kg} \mathrm{~m}^{-2} \mathrm{yr}^{-1}$ after 2 yr. By then the blocks stuck out on their isolated platforms, while the grazers continue to remove the reef around them and change its topography. This site also had the highest density of Echinometra mathaei $\left(210 \pm 60.4 \mathrm{~m}^{-2}\right)$ of any of the study sites, suggesting that these sea urchins are responsible for the high rates of substrate loss. The corrected values for in situ total carbonate removal by grazing at Faaa of up to $25 \mathrm{~kg} \mathrm{~m}^{-2} \mathrm{yr}^{-1}$ are closely comparable with high rates reported in a recent study of Reaka-Kudla et al. (1996), who used similar techniques at Champion Island of the Galapagos, on a reef that was severely impacted by the 1982-1983 El Niño Southern Oscillation event (Macintyre et al. 1992, Glynn 1994). Their estimated rates of substrate loss were $25.4 \mathrm{~kg} \mathrm{~m}^{-2} \mathrm{yr}^{-1}$. They also found that in the $14 \mathrm{mo}$ of their bioerosion experiments the 3-dimensional topography of the reef changed dramatically. They suggested that grazing by sea urchins as well as several species of herbivorous fish was responsible for the extremely high rates of substrate loss. Similar studies by Bak (1990) in

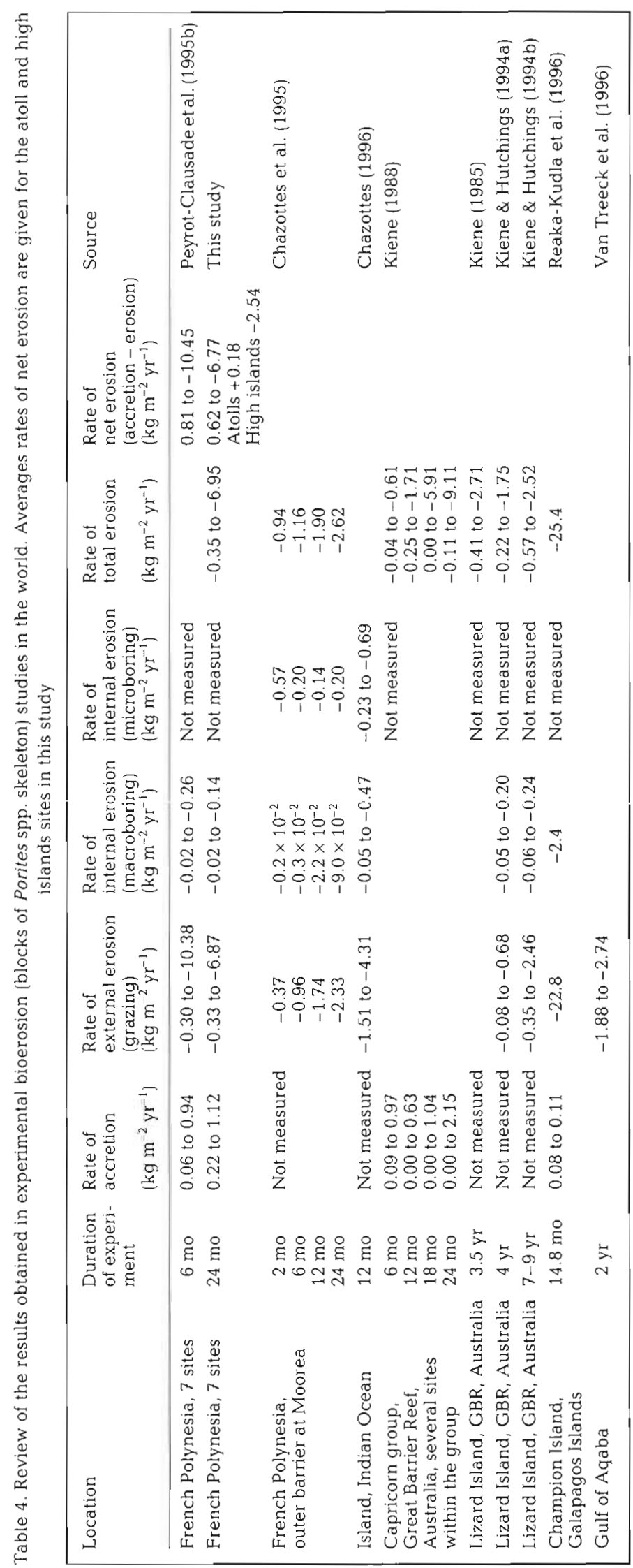


French Polynesia have shown that the sea urchins can consume $12.5 \mathrm{~g}$ of $\mathrm{CaCO}_{3} \mathrm{~m}^{-2} \mathrm{~d}^{-1}$, which is equivalent to $4.51 \mathrm{~kg} \mathrm{~m}^{-2} \mathrm{yr}^{-1}$. Few scarids were observed at the high island sites except on Moorea, where they are abundant (Peyrot-Clausade et al. 1995b).

At the atoll sites, where no sea urchins were present, scarids were probably responsible for the losses observed $\left(0.33 \pm 0.20\right.$ to $\left.0.86 \pm 0.45 \mathrm{~kg} \mathrm{~m}^{-2} \mathrm{yr}^{-1}\right)$. At Lizard Island, Great Barrier Reef, a 'healthy' reef, rates of loss due to external grazing were estimated at $0.59 \pm 0.25$ to $2.52 \pm 0.38 \mathrm{~kg} \mathrm{~m}^{-2} \mathrm{yr}^{-1}$, and were due almost entirely to scarids (Kiene \& Hutchings 1994a, b). Kiene \& Hutchings (1994a) postulated that lower levels of grazing by scarids at deeper sites at Lizard Island were related to lower levels of algal content in the substrate. Bruggeman et al. (1996) showed that the highest bioerosional rates by scarids occurred on shallow reefs ( $7 \mathrm{~kg} \mathrm{~m}^{-2} \mathrm{yr}^{-1}$ ) and decreased with reef depth.

Losses of substrate are caused not only by grazers, but also by macroborers. We suggest that rates of loss attributed to macroborers in this study $10.02 \pm 0.02$ to $0.14 \pm 0.25 \mathrm{~kg} \mathrm{~m}^{-2} \mathrm{yr}^{-1}$ ) are probably underestimated. This is because a part of the burrow is removed by grazing and it is difficult to differentiate the holes made by small polychaetes from structural cavities of the coral skeleton on the scanned images. It is also difficult to distinguish between algal filaments and small burrows in the surface layers of the blocks. We found many small polychaetes in the algal residue after acid dissolution of substrate blocks. Currently, we are not aware of any better method of estimating rates of substrate loss attributable to boring by macrofauna, as they often live in burrows that are much larger than themselves. In addition, many of the smallest polychaetes have short life cycles and thus several generations may have occupied a block exposed for 2 yr (Hutchings et al. 1992). The composition of polychaete populations in this study changed over time with an increasing number of longer lived members of the family Eunicidae.

\section{Interactions}

Bioerosion in the coral reef environment is the result of complex interactions between accretion, grazing and internal erosion. Evidence of all 3 activities is present in the current experimental series; however, their individual contributions are difficult to assess on the basis of 2 time profiles of collection and evaluation ( 6 mo and 2 yr). In our evaluation, therefore, the result of this interaction is presented as cumulative net erosion, i.e. residual volume of accreted substrate minus internal and external substrate loss, with reference to the original yolume and weight of the exposed blocks.
The initial colonization of exposed blocks is micro-

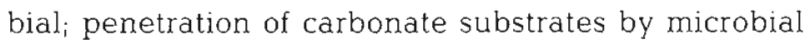
endoliths occurs within weeks (Chazottes et al. 1995). In the shallow tropical waters at Moorea, the relative contribution of phototrophic microbial endoliths to total bioerosion after 2 mo was $60 \%$, amounting to a removal rate of $0.6 \mathrm{~kg} \mathrm{~m}^{-2} \mathrm{yr}^{-1}$ of carbonate. These primary producers are the principal initial food source for grazers Their downward growth orientation and fast recovery rates permit a rapid progression of total carbonate removal (Schneider \& Torunski 1983) from 0.9 to $2.6 \mathrm{~kg}$ $\mathrm{m}^{-2} \mathrm{yr}^{-1}$ at Moorea (Chazottes et al. 1995).

The accretion by epilithic crustose rhodophytes becomes established later. It protects the substrate and counterbalances external erosion by grazing. Thus, net removal of the exposed substrates occurs prior or intermittent to the periods when the substrate is covered by encrusting algae. For example, Faad, which had the highest level of net loss from grazing, also had the lowest level of algal accretion. A similar study carried out on a Caribbean reef (Hackney et al. 1989) showed that the crusts of coralline algae survived greater grazing intensities than turfs, suggesting that the former are better adapted to resist grazing. In our study, the atoll sites, in general, showed a higher rate of accretion by crustose algae, probably due to the absence of sea urchins, than the sites on high islands, almost completely compensating for grazing pressure.

Apparently, high levels of grazing do not prevent the establishment of large infaunal populations which contribute to internal substrate erosion. For example, high external erosion rates on high islands are correlated with high levels of infaunal biomass and density. In addition, it is conceivable that internal erosion sufficiently weakens the substrate, which may, in turn, enhance grazing efficiency. Generally, high levels of suspended organic matter at the high island sites favors growth of infaunal suspension feeders in blocks, which is in sharp contrast to the low biomass and densities of suspension feeders in oligotrophic waters of atolls.

Similar and relatively even distribution of total organic content in the exposed blocks throughout the range of studied sites, despite clear differences in trophic levels of the surrounding waters, is surprising. This finding indicates that the overall rates of organic production and consumption may be different but balanced.

\section{Patterns of erosion}

Carbonate budgets of experimental substrates in atoll lagoons after 2 yr seem to be balanced. So Tik. 2 and Tak. 2, exhibiting negative budgets after 6 mo $\left(-0.20\right.$ and $\left.-0.38 \mathrm{~kg} \mathrm{~m}^{-2} \mathrm{yr}^{-1}\right)$, respectively, and Tak. 1, 
exhibiting a positive budget after 6 mo $\left(0.81 \mathrm{~kg} \mathrm{~m}^{-2}\right.$ $\mathrm{yr}^{-1}$ ), tend to reach equilibrium after 2 yr (erosion balanced by accretion).

There is a large difference in carbonate budget between atolls and high islands after 2 yr. At Moorea the negative budget is more marked after $2 \mathrm{yr}(-0.38 \mathrm{~kg}$ $\left.\mathrm{m}^{-2} \mathrm{yr}^{-1}\right)$ than it was after 6 mo $\left(0.04 \mathrm{~kg} \mathrm{~m}^{-2} \mathrm{yr}^{-1}\right)$. At Faaa, however, it should be noted that the net loss tends to decrease with time (length of exposure) from $-10.45 \mathrm{~kg} \mathrm{~m}^{-2} \mathrm{yr}^{-1}$ after $6 \mathrm{mo}$ against to $-6.77 \mathrm{~kg} \mathrm{~m}^{-2}$ $\mathrm{yr}^{-1}$ after $2 \mathrm{yr}$. This site, distinguished from the others by the highest net rate of loss after 6 mo of exposure, maintained a marked negative budget after $2 \mathrm{yr}$.

The pattern set within the first 6 mo of exposure (Peyrot-Clausade et al. 1995b) was maintained after 2 yr (this study). Kiene \& Hutchings $(1994 \mathrm{a}, \mathrm{b})$ found that patterns of bioerosion (grazing and boring) established at a particular site within the same reefal system (Lizard Island, Great Barrier Reef) after 2 yr of exposure were generally maintained for the following 5,7 and 9 yr.

This study revealed unusually low rates of internal erosion by macroborers. This is consistent with the virtual absence of boring sponges in the studied blocks. Similar conditions were also observed at Lizard Island, Australia (Kiene 1988). Clionid sponges are known to be the most efficient borers (Rose \& Risk 1085).

A summary of data from recent works that used a similar experimental approach to this study is presented in Table 4. Spencer (1992) also tabulated rates of grazing and boring by a variety of organisms. The table shows that variations exist between areas; however, all figures except for those from highly degraded reefs (Faaa and Galapagos) are within the same order of magnitude. Low bioerosion rates have been largely found whatever the geological history of the site or the population of organisms responsible for grazing and boring. However, high rates of bioerosion may be a good measure of disturbances in coral reef functioning due to sewage (Faaa) or to natural events such as El Niño (Galapagos). Perhaps this means that we can start defining baselines for rates of bioerosion and accretion for healthy reefs and using them to assess the condition of a reef

Acknowledgements. This study was made possible by a grant from the French-Australian cooperation in Marine Sciences to M.P.C. and an Australian-French cooperative grant from DITAC (Department of Industry, Technology and Regional Development) to P.H. We also thank the following persons for assistance in the field or providing logistical support: Joell Orempuller of ORSTOM, Papeete; James Algret of CriobeMoorea; and Christophe Brié of EVAAM-Takapoto. Kate Attwood undertook some of the preparation of samples in Sydney and Rob Patterson prepared the coral blocks.

\section{LITERATURE CITED}

Adjeroud M (1996) Biodiversité dans un écosystème corallien insulaire (Moorea, Polynésie Française): analyse de la répartition spatiale de la biodiversité des peuplements mégabenthiques et relations avec les facteurs environnementaux. Thèse de Doctorat de l'Université Paris 6 et de l'EPHE

Bak RPM (1990) Patterns of echinoid bioerosion in two Pacific coral reef lagoons. Mar Ecol Prog Ser 66:267-272

Bellwood DR (1995a) Direct estimate of bioerosion by two parrotfish species, Chlorurus gibbus and C. sordidus, on the Great Barrier Reef, Australia. Mar Biol 121:419-429

Bellwood DR (1995b) Carbonate transport and within-reef patterns of bioerosion and sediment release by parrotfishes (family Scaridae) on the Great Barrier Reef. Mar Ecol Prog Ser 117:127-136

Bliss CI (1967) Statistics in biology, Vol 1. Statistical methods for research in the natural sciences. McGraw Hill, New York

Bouchon C (1985) Quantitative study of scleractinian corals communities of Tiahura reef (Moorea Island, French Polynesia). Proc 5th Int Coral Reef Congr 6:279-284

Bromley RG (1975) Comparative analysis of fossil and recent echinoid bioerosion. Palaeontology 18:725-739

Bromley RG, D'Alessandro A (1990) Comparative analysis of bioerosion in deep and shallow water, Pliocene to Recent, Mediterranean Sea. Ichnos 1:43-49

Bruggeman JH, van Kessel AM, van Rooij JM, Breeman AM (1996) Bioerosion and sediment ingestion by the Caribbean parrotfish Scarus vetula and Sparisoma viride: implications of fish size, feeding mode and habitat use. Mar Ecol Prog Ser 134:59-71

Cariès JC (1991) Surveillance de la qualité du milieu marin dans la circonscription du Port futónome de Papeete et autour de Tahiti dans le cadre du Réseau Territorial d'observation. Proc ISRS Congr Nouméa:17-24

Charpy L (1996) Phytoplankton biomass and production in two Tuamotu atoll lagoons (French Polynesia). Mar Ecol Prog Ser 145:133-142

Chazottes V (1996) Etude expérimentale de la bioérosion et de la sédimentogénèse en milieu récifal: effets de l'eutrophisation (île de la Réunion, Océan Indien). C R Acad Sci Paris 323:787-794

Chazottes V, Le Campion-Alsumard T, Peyrot-Clausade M (1995) Bioerosion rates on coral reefs: interactions between macroborers, microborers and grazers (Moorea, French Polynesia). Palaeogeogr Palaeoclimatol Palaeoecol 63:275-291

Eakin CM (1996) Where have all the carbonates gone? A model comparison of calcium carbonate budgets before and after the 1982-1983 El Niño at Ulva Island in the eastern Pacific. Coral Reefs 15:109-119

Faure G, Laboute P (1984) Formations récifales de l'atoll de Tikehau (Tuamotu, Polynésie française, Océan Pacifique. 1. Définition des unités récifales et distribution des principaux peuplements de scléractinaires. ORSTOM Notes Doc 22:108-136

Fiege K (1993) Bioeroders in fossil reefs. Facies 28:109-114

Fraizier A, Franck D, Benente P, Jouen R, Debiard JP (1985) Observations on the various forms of pollution of the Tahiti lagoons. Proc 5th Int Coral Reef Congr 6:445-451

Frigge M, Hoaglin DC, Iglewicz B (1989) Some implementations of boxplot. Am Stat 43:50-54

Gabrié C, Galzin R, Salvat B (1988) Activités humaines et récifs coralliens Moorea Rapport RA 27, Antenne Museum-EPHE. Moorea

Gabrié C, Payri C. Salvat B (1986) Etude du plan d'aménage- 
ment du milieu à Atimaono. Etude d'environnement en milieu récifal Analyse de l'état initial. Rapport RA 19A, Antenne Museum-EPHE, Moorea

Glynn PW (1994) State of coral reefs in the Galapagos Islands: natural versus anthropogenic impacts. Mar Pollut Bull 29 $131-140$

Glynn PW (1997) Bioerosion and coral-reef growth: a dynamic balance. In: Birkeland C (ed) Life and death of coral reefs. Chapman \& Hall, New York, p 68-95

Hackney JM, Carpenter RC, Adey WH (1989) Characteristic adaptations to grazing among algal turfs on a Caribbean coral reef. Phycologia 28:109-119

Harmelin-Vivien ML (1985) Tikehau Atoll, Tuamotu Archipelago. Proc 5th Int Coral Reef Congr 1:211-268

Harmelin-Vivien ML (1994) The effects of storms and cyclones on coral reefs: a review. J Coastal Res Spec Issue $12: 211-231$

Harmelin-Vivien ML, Peyrot-Clausade M, Romano JC (1992) Transformation of algal turf by echinoids and scarid fishes on French Polynesian coral reefs. Coral Reefs 11:45-50

Hutchings PA (1981) Polychaete recruitment onto dead coral substrates at Lizard Island, Great Barrier Reef, Australia. Bull Mar Sci 31:410-423

Hutchings PA (1986) Biological destruction of coral reefs. A review. Coral Reefs 4:239-252

Hutchings PA, Kiene WE, Cunningham RB, Donelly C (1992) Spatial and temporal patterns of non-colonial boring organisms (polychaetes, sipunculans, and bivalve molluscs) in Porites at Lizard Island, Great Barrier Reef. Coral Reefs 11:23-32

Hutchings PA, Payri C, Gabrié C (1994) The currents status of coral reefs management in French Polynesia. Mar Pollut Bull 29:26-33

Hutchings PA, Weate PB (1978) Comments on the technique of acid dissolution of coral rock to extract endo-cryptolithic fauna. Aust Zool 19:315-320

Kiene WE (1985) Biological destruction of experimental coral substrates at Lizard Island, Great Barrier Reef, Australia. Proc 5th Int Coral Reef Symp 5:339-344

Kiene WE (1988) Biological destruction on the Great Barrier Reef. PhD thesis, Australian National University, Canberra

Kiene WE, Hutchings PA (1994a) Experimental investigations on patterns in the rates of bioerosion at Lizard Island, Great Barrier Reef, Coral Reefs 13:91-98

Kiene WE, Hutchings PA (1994b) Long-term bioerosion of experimental substrates from Lizard Island, Great Barrier Reef. Proc 7th Int Coral Reef Symp 1:397-403

Laubier L (1962) Le coralligène des albères. Ann Inst Oceanogr 43:137-316

Macintyre IG, Glynn PW, Cortés J (1992) Holocene reef history in the eastern Pacific: mainland Costa Rica, Caño Island, Cocus Island and Galápagos Islands. Proc 7th Int Coral Reef Symp 2:1174-1184

Musso B (1997) Internal Bbioerosion in living and dead corals on the Great Barrier Reef. PhD thesis, James Cook University, Townsville

Peyrot-Clausade M (1989) Crab cryptofauna (Brachyura and Anomura) of Tikehau, Tuamotu Archipelago, French Poly-

Editorial responsibility: Otto Kinne (Editor),

Oldendorf/Luhe, Germany nesia. Coral Reefs 8:109-117

Peyrot-Clausade $M$, Le Campion-Alsumard $T$, HarmelinVivien M, Romano JC, Chazottes V, Pari N, Le Campion J (1995a) La bioérosion dans le cycle des carbonates: essais de quantification des processus en Polynésie française. Bull Soc Géol Fr 166:85-94

Peyrot-Clausade $M$, Le Campion-Alsumard T, Hutchings $P$, Payri C, Fontaine M (1995b) Initial bioerosion and bioaccretion on experimental substrates in high island and atoll Jagoons (French Polynesia). Oceanol Acta 18:531-541

Reaka-Kudla M, Feingold JS, Glynn W (1996) Experimental studies of rapid bioerosion of coral reefs in the Galapagos Islands. Coral Reefs 15:101-107

Rose CS, Risk MJ (1985) Increase in Cliona delitrix infestation of Montastrea cavernosa heads on an organically polluted portion of the Grand Cayman fringing reef. PSZN I: Mar Ecol 6:345-363

Roux M (1985) Algorithmes de classification. Methodes et programmes. Masson, Paris

Sachs L (1982) Applied statistics: handbook of techniques Springer Verlag, New York

Salvat B, Richard G (1985) Takapoto Atoll, Tuamotu Archipelago. Proc 5th Int Coral Reef Symp 1:323-378

Sammarco PW, Risk M (1990) Large-scale patterns in internal bioerosion of Porites: cross continental shelf trends on the Great Barrier Reef. Mar Ecol Prog Ser 59:145-156

Sammarco PW, Risk M, Rose C (1987) Effects of grazing and damselfish territoriality on internal bioerosion of dead corals: indirect effects. J Exp Mar Biol Ecol 112: $185-189$

Saporta G (1978) Théories et méthodes de la statistique. Technip, Paris

Schaefer A (1970) Les bases mathémathiques de la microstéréologie. Microskopion 18-19:3-14

Schneider J, Torunski H (1983) Biokarst on limestone coasts, morphogenesis and sediment production. PSZN I: Mar Ecol 4:45-63

Spencer T (1992) Bioerosion and biogeomorphology. In: John DM, Hawkins SJ, Price JH (eds) Plant-animal interactions in the benthos. Syst Assoc Spec Vol 46:493-509

Stat-Itcf (1991) Manuel d'utilisation. Institut Technique des Céréales et des Fourrages, Paris

Statview 4.5 (1996) Manuel utilisateur. Abacus Concepts Inc Berkeley, CA

Super Anova 1.11 (1991) Manuel utilisateur. Abacus Concepts Inc, Berkeley, CA

Van Treeck P. Schuhmacher H, Paster M (1996) Grazing and bioerosion by herbivorous fishes - key processes structuring coral reef communities. In: Reitner J, Neuweiler F, Gunkel $F$ (eds) Global and regional controls on biogenic sedimentation. I. Reef evolution. Research Reports, p 133-137

Wolanski E, Delesalle B, Dufour V, Aubenel A (1993) Modelling the fate of pollutants in the Tiahura Lagoon, Moorea, French Polynesia. 11th Australian Conference on Coastal and Ocean Engineering, Townsville, p 583-588

Zar JH (1984) Biostatistical analysis. Prentice and Hall, Englewood Cliffs, $\mathrm{NJ}$

Submitted: July 29, 1997; Accepted: January 26, 1998

Proofs received from author(s): May 12, 1998 